\title{
Hol UNITED NATIONS RESEARCH LABORATORIES
}

$I^{\mathrm{N}}$ October 1946 the Economic and Social Council of the Unitedh Nations adopted by a large majority a resolution . Nmitted by the French delegation calling son the Secretary-General, in consultation with th ise Inn and the other specialized agencies concerned, topir tort upon the problem of establishing United Natons Research Laboratories Two parallel inquiries were made, the results of which have now been published*; the first was conducted by the Secretary-General, and the second by Unesco. The Unesco report occupies some seventy pages of the annexes, and with it appear replies from the World Health Organisation, the International Labour Organisation, the United Nations Food and Agriculture Organisation as well as from the International Council of Scientific Unions and six of the individual Unions, from the World Power Conference and like organisations, the Rockefeller Foundation and from forty-two individual scientific men, including $\mathrm{Dr}$. K. T. Compton, Sir Charles Darwin, Prof. A. Einstein, Prof. A. V. Hill, Prof. Harlow Shapley, Prof. H. C. Urey and Prof. S. Zuckerman.

Generally, the opinion elicited by the SecretaryGeneral's inquiry was favourable to the principle of international research, though many notes of caution were sounded. While some favoured an international research establishment, believing it would advance research activity in most branches of science, this omnibus conception of United Nations laboratories caused misgivings to others. Some replies suggested that the purpose of an international research establishment should be to maintain and develop important branches of scientific research which, for one reason or another, scientific men to-day are inclined to neglect. Others stressed the function which United Nations laboratories might perform in fields such as astronomy that can only be developed rationally on an international level; while besides those problems that require a crossing of national boundaries, there are others, such as arctic, antarctic and oceanic studies, which must be investigated outside the boundaries of any given State. Attention was also directed to the need for international standards and units of measurement, and many replies indicated a desire for international research in fields that are of immediate and vital concern to all nations; for example, agricultural science, medicine and public health.

Four main arguments were urged against United Nations action. The first, based on consideration of expense, sprang from the demand for increased financial resources coming from existing institutions and the fear that the establishment of central laboratories might be disadvantageous to existing institutions. The second objection related to the scientific staff which would be required for the international laboratories; in this respect, also, such laboratories would be competing with existing institutions, many of which are already understaffed. On the other hand, it was suggested that international laboratories, by providing training facilities, would help the small nations to expand their staff of experts and thus ease the situation. A third objection related

* United Nations: Department of Social Affairs. The Question of Establishing United Nations Research Laboratories. Pp. viii +290. (New York: Lake Success; London: Russell Square House, 1949.) 2 dollars. to specific research centres : there were fields, such as mathematical research, in which it was suggested no international organisation could assist. The fourth objection centred on co-ordination, urging that, in the present stage of scientific co-ordination in the international sphere, the proposal was premature.

Generally speaking, the international scientific unions appear to be strongly in favour of the principle, as was Unesco and, in certain fields, the International Labour Organisation. The International Civil Aviation Organisation favours an international research centre for cartography and meteorology; but the World Health Organisation wishes to reserve the right to choose and execute any projects in the medical field. The Food and Agriculture Organisation does not at present favour international centres, preferring to encourage the scientific work of national institutions.

The Secretary-General's report then discusses specific suggestions received for international research. A number of these appear in the comprehensive and systematic report submitted by Unesco. The latter report begins by outlining certain principles which should determine the validity of any such proposals for international research : thus the subject should be appropriate for such development; it should be one in which the new knowledge can only be acquired in places remote from the existing main centres of science; it should be one requiring organisation on zonal lines or the crossing of national boundaries or international pooling. The Unesco report furthermore suggests that, so far as possible, the existing international scientific unions should take the major scientific responsibility. Among the projects given detailed study by Unesco are international astronomical observatories, laboratories of nutritional science and food technology, meteorological institutes and stations, institutes of applied mathematics (computing machines), centres for the study of tropical life and resources, international ornithological observatories and international oceanographic institutes.

The Secretary-General's report was considered by the Economic and Social Council at its seventh session on August 10, 1948, when the Council adopted a resolution urging that the problem should be further discussed by the governing bodies of all the important national scientific institutions for higher education and research, and authorizing the Secretary-General, in co-operation with Unesco, to form a small committee of experts to examine the question. That committee of eight experts, including Dr. J. Needham and A. T. M. Wilson of Great Britain, and Dr. Harlow Shapley and Dr. R. Likert of the United States, met in Paris last August and had before it almost a hundred individual proposals. Its formal report has not yet been issued; but it is understood that in appraising these proposals the Committee laid considerable emphasis on the value of each project to humanity, from a scientific and a practical point of view, on the appropriateness of the project for research at an international level, on the resources available, the probable cost, the risk of duplication and on whether the project is in an under-developed field greatly in need of stimulation.

Three projects were selected by the Committee as of first importance : an International Computation 
Centre, an Institute for Neurophysiology and an Institute of the Human Sciences. The first and last of these were recommended for immediate establishment by the National Research Council of the United States Committee on Unesco. A third proposal, for an Institute of Geo-Medicine, which had also been endorsed by the National Research Council Com. mittee, was referred to the World Health Organisation. High priority was also recommended for four further proposals: an Arid Zone Laboratory, an International Astronomical Laboratory, an Institute for the Chemistry of Living Matter, and a Meteorological Institute. It is understood that the Committee of Experts proposes to call a conference of fifty to sixty scientific men during the summer of 1951 to discuss the entire programme for United Nations research laboratories, reviewing the achievements of the first three Institutes which are expected to be operating by that time, and examining additional proposals. Meanwhile, the Director-General of Unesco has indicated that the Organisation is already actively concerning itself with the proposal for an Institute for the Arid Zones, and is also considering the creation of international pool facilities for scientific standards and type collections.

The Committee on Unesco of the U.S. National Research Council, in commenting on the report and subsequent developments, rightly urges the responsibility of scientific men, pending the official report of the Committee of Scientific Experts, for the examination of the material already available, with the view of forming considered opinions on the subject, so that their national representatives may have clear guidance when the time for decisive vote for or against the proposals arrives. The National Research Council Committee itself has set forth clearly principles which should be met by any such proposal worthy of consideration by the United Nations. Support, in its opinion, should be limited to those projects which meet one or more of the following five qualifications : study in a large number of countries is essential to the prosecution of the problem; apparatus and technical assistance is too expensive to be supported by single nations alone; the scientific results sought are likely to be of value to many countries; a particularly favourable site for a particular study is available in a country unable financially to support the project; and the project bears specially on the aims of the United Nations.

The National Research Council Committee, while urging the immediate establishment of three Institutes, is keenly aware that the creation of a new United Nations research institute is not lightly to be recommended. It is the great merit of the report with annexes now issued by the United Nations that reasoned statements accompanied such proposals. In particular is this true of Dr. R. J. Dubos's memorandum urging the creation of an international laboratory for the study of tuberculosis, Dr. R. J. L. Pluvinage's plan for an international brain institute, Prof. P. Gourou's research and experimental programme for the improvement of agriculture and standards of life in tropical regions, Dr. H. L. Shapiro's memorandum on research on the adaptation of man to its environment, and Dr. Harlow Shapley's project for an international laboratory for astronomical research.

There is a wealth of material in the report for study, and it is impossible to do justice to much of it in a summary. Mention should, however, be made of the reply from the Rockefeller Foundation, in view of the long international experience of that body. The Rockefeller Foundation has certain reservations, which would be valid at any time, about starting new international institutes, and considers that the present position regarding scientific staff strengthens those reservations. Accordingly, the reply emphasizes the wisdom in developing international co-operation in science, of working so far as possible by aiding and improving the existing organisations. Secondly, the Rockefeller Foundation suggests that at the present time the critical need is not so much advanced laboratories as adequately trained staff. The emphasis is thus shifted rather to the support of existing institutes which are effectively coupled with universities so that they serve the double purpose of recruitment and training and of actual research output. In the critical dearth of first-class personnel at the present time, the Rockefeller Foundation finds it difficult to see where the necessary leadership for new institutes could be obtained. The Foundation also views with concern the tendency to locate new international institutes in places where they are not needed or cannot be properly utilized, and its experience emphasizes the desirability of establishing a good balance between local (or national) support and support from any outside agency.

Apart from challenging what the Unesco report terms the principle of remoteness, this rather cautious reply does not controvert the other principles laid down by Unesco. It is on the question of timing that the Rockefeller Foundation has reservations, and its observations on the staff position deserves to be weighed very carefully. The same objection is not, however, raised in the replies received from the International Council of Scientific Unions or the International Scientific Unions, nor does there appear to be any concern there that the support of any such new institutions will adversely affect Unesco's support of the International Unions themselves. Specific projects advocated in the replies from the Unions relate to an international observatory, floating laboratories for work in geodesy and geophysics, development of the International Latitude Service, an international cartographical organisation, an international organisation for the study of erosion, and an arid zone research laboratory for fluid and soil mechanics. Prof. J. Timmermans, replying for the International Union of Chemistry, visualizes international centres for the collection and handling of pure products, and groups or research centres for standardizing systems and apparatus and supervising the constants of substances used as standards, as well as for certain astronomical studies, meteorological observations and the study of the distribution and development of certain species of living creatures.

The United Nations has issued a report which merits close study. The objections to any such new proposals are clearly set forth, and, though the Committee of Experts appears to be going ahead, there is no reason to fear that unsound or untimely projects will command its support. It is true that in certain fields the staff position may render action premature at the moment, but the broad proposal does appear to offer an effective means of securing that the advance of science proceeds on a broader front; its implementation is well calculated to increase the co-operation and intermingling of minds at the frontiers of several disciplines and branches of science which has in the past been such a fruitful stimulus of creative thought. 